Nidhomul Haq: Jurnal Manajemen Pendidikan Islam

E-ISSN: 2503-1481

TerakreditasiRistekdikti: 28/E/KPT/2019

Hal: 347-359

DOI: https://doi.org/10.31538/ndh.v5i3.967

http://e-journal.ikhac.ac.id/index.php/nidhomulhaq

\title{
HOW THE RESEARCH SKILLS DEVELOPMENT FRAMEWORK MAY BE USEFUL FOR INDONESIAN HIGHER EDUCATION LEARNING PRACTICE
}

\author{
Oskar Hutagaluh' ${ }^{1)}$, Sardjana Orba Manullang(2) Muliyadi Hamid ${ }^{3)}$ Abdul Samad Arief ${ }^{4}$ \\ Dayan Abdurrahman ${ }^{5}$ \\ ${ }^{1}$ Institut Agama Islam Sultan Muhammad Syafiuddin Sambas, Indonesia \\ oskarhutagaluh@iaisambas.ac.id \\ ${ }^{2}$ Universitas Krisnadwipayana, Indonesia \\ somanullang@unkris.ac.id \\ ${ }_{3}^{3}$ Universitas Fajar, Makassar, Indonesia \\ mulham66@yahoo.com \\ ${ }^{4}$ Universitas Fajar, Makassar, Indonesia \\ abdulsamad@unifa.ac.id \\ ${ }^{5}$ Sekolah Tinggi Keguruan dan Ilmu Pendidikan An-nur Nangro Aceh, Indonesia \\ dayanbintang@yahoo.com
}

\begin{abstract}
Abstrak
Penelitian kualitatif ini bertujuan untuk meninjau kegunaan Kerangka Pengembangan Keterampilan Penelitian (RSD) di kalangan mahasiswa perguruan tinggi di Indonesia. Konsep RSD telah berkontribusi pada model pembelajaran berbasis penelitian di kalangan siswa di Australia dan negara barat lainnya, baik di kalangan siswa sekolah dasar maupun perguruan tinggi. Karena kerangka kerja penelitian ini berhasil di banyak negara, kami berencana untuk meninjau dan melihat kegunaan kerangka RSD bagi kalangan akademik di Indonesia. Untuk memudabkan peninjauan inï, kami telah mencoba mereview beberapa dokumen penting terkait dengan konsep, penerapannya, evaluasi beserta rubrik penilaiannya dari kerangka riset ini. Selanjutnya, kami melaporkannya sebagai dokumen pengenalan kerangka pengembangan penelitian. Dengan harapan dokumen ini menjadi cikal bakal pengenalan dan pengembangan di kalangan perguruan tinggi khususnya yang sedang menyelesaikan tugas-tugas akademik yang melibatkan keterampilan penelitian untuk keperluan publikasi atau tujuan pengembangan kecakapan riset akademik. Namun, banyak hal yang akan menantang studi semacam ini, sesuatu yang baru bagi konsep studi konfirmatif di Indonesia, termasuk beberapa istilah baru dalam kerangka riset yang membutubkan notasi pemahaman baru.
\end{abstract}

Kata Kunci: Pengembangan Keterampilan Riset, Pembelajaran Perguruan Tinggi, dan Studi Kualitatif.

\begin{abstract}
This qualitative research aimed to review the usefulness of Research Skills Development framework (RSD) among higher education students in Indonesia. The RSD concept has contributed to research-based learning models among students in Australia, both among elementary and tertiary school students. Due to this research framework's success in Australia, we plan to review and see the usefulness of the RSD framework to university students in Indonesia. To facilitate this introduction, we have tried to review several important documents related to this $R D S$ concept, application, evaluation together with rubric assessment. Furthermore, we reported it as a document to the introduction to the research development framework. With the hope that this document will be the forerunner of introduction and development among students, especially those who are completing academic assignments involving research skills for publication purposes to assess academic communication skills. However, many things will challenge this kind of study, something new to the concept of confirmative studies in Indonesia, including several new terms in the research framework that require new understanding notations.
\end{abstract}

Keywords: Research Skills Development, Higher Education Students, and Qualitative Study 


\section{INTRODUCTION}

The development of research skills in a higher education learning environment is essential and mandatory. (Pretorius et al., 2013; Laidlaw et al., 2012; Wibawa, 2017). Because with this highly academic competency, students will have more opportunities to be involved in obtaining information, processing, and communicating it for various purposes, such as marking each class subject mastery or evaluating system based on publications in university journals or other industries. In other words, if higher education community are involved in and come into contact with research enrich learning, then they will quickly become strong capability individuals during college or working in the professional world employment upon graduation later. Therefore, the helping hand of the parties to succeed in the transfer of this academic mindset skill to the Indonesian academic community is urgent so that the acceleration of researchbased learning is more focused and based on intellectual society.

Through this research-based learning skill, many parties will be lucky apart from the students themselves. For example, universities will be able to promote the academic community's relevance and abilities to meet the demands of the competitive world of work that have emerged in the twenty-first century's digital competition. Also, enhancing the link between research skills and teaching and learning work to strengthen each other's identities. Research expertise at the tertiary level will also help academics improve their independent study skills such as online self-study during the COVID-19 pandemic because the characteristics of pursuits at the postgraduate level are based on independent study skills and high motivation. Anyone can now ask why institutions of higher education should improve their community research skills? The answer is that in general, higher education institutions require the ability of each student to have critical thinking skills in collaborative problem-solving. They are learning collaboration between students and lecturers as well as students and fellow students. They can learn through expertise for evaluation and work constructively with fellow academic communities collaboratively. It is the primary goal of teaching in higher education, which is based on research learning and working.

There are many models and concepts for developing research skills that have now entered the higher education environment, especially in higher education in western countries. One of them is the Research Skill Development (RSD) framework. This research 
framework is a research model developed in Australia's leading universities in 2007 (J. Willison \& O'Regan, 2007). This study framework model has been used extensively in academia to develop or innovate a research-based curriculum equipped with an evaluation rubric. (Aslan, 2018; Aslan, 2019; Aslan \& Wahyudin, 2020). Torres \& Jansen (2016) suggested that academics may now work from different pages, but they still may be in a collaborative work approach researching and developing their community's ability to use similar learning methods. For this matter, the use of research skills to support students' research skills in many different universities across countries. The development of this study workbook is used for the first time to help students develop student study skills that can help more academicians in a gradual and structured manner.

Fortuin \& Van Koppen (2016) examined teaching and learning approaches that could use intuitive skills by involving inter- and transdisciplinary research. They are adopting the framework and applying it to environmental knowledge education in various knowledge disciplines. So, this model has related to the framework model owned by RSD, which has proven this framework is a means of learning high useful pedagogical values that allow students and lecturers to collaborate with librarians, academic skills supervisors, and other academics who make efforts to enrich their assessment and assessment skills. Those who have become the mandatory task of academics, especially students, have research power as part of learning in modern times described precisely and efficiently.

A recent study by Mataniari et al., (2020) had strengthened the benefits possessed by this research framework concept where they had described how the academic skills of Indonesian students in the cognitive realm of critical thinking when they were with the RSD framework model in one of the case studies in the Biology education course at the University of Indonesia. Many other studies have also shown that students will benefit if they are successfully involved in various research activities such as the RSD framework both as students and enter the professional world. Students' research experience is beneficial and allows them to quickly learn various knowledge and updates in the published intellectual world. In this way, students can continue to balance collaborative learning, helping to sharpen the scientific programs' field to be easier to start a career when they are involved in various kinds of the professional world, especially fields of work that require 
research skills. Thus, the skill that is needed is the involvement of students at the higher education level, namely the acuity in completing work related to research. These skills can also have a positive impact on the development of their learning and academic assignments. If these skills are healthy, they will allow them to quickly move into a professional career into a highly competitive world of work.

The study of Baker \& Pifer, (2011) has indicated that there is a role of a close relationship in the deepening of research skills similar to the RSD concept in the transition period from doctoral students to scientists and scholars who are more independent in a career in the world of work involving elements of research and scholarship of teaching and dissemination of science and renewal. Although this transition period can be guided and encouraged during the learning experience, there is often a gap between the skills required for higher education and the minimum skills requirements for the world of work in various industries or academia. To bridge this gap, students own and connect students in a more directed way with today and future professional world demands.

This research aimed to introduce a learning research framework to encourage the development of the higher education community's research skills from students, lecturers, curriculum teaching researchers, and education policymakers to facilitate with a research-based learning model in the style of Australian and national education standards other west. It is with the hope that these studies can promote the Indonesian academic community's success and develop research capability, which is a key component in the 21stcentury education world, which is Indonesia's national agenda. This initiative aims to provide practical input and direction to curriculum development teams and lecturers in Indonesia who have created and carried out research activities in the academic community but have never applied a research framework model such as RSD. This framework identifies the skills and potential for student autonomy and assessment criteria at the course level of each student, This model in the RSD framework guides overall structure, development of study questions that discover and generate new knowledge, evaluate and reflect on, organize, analyze, synthesize, and communicate research findings.

In the lower level of education, this research development model. Students can function in a controlled study room to gain experience in applying skills and research 
methods following the length of education. In higher education, students can train more with allocation and autonomy in developing their study topics and choosing development sources, methods, approaches, and ways of disseminating external study results such as seminars and scientific publications. The use of this RSD research framework will ensure alignment and appropriateness to explore student research competencies with the ultimate goal of all levels of education and programs in Indonesia. This RSD framework also provides a basic understanding for the enrichment of research skills to a higher stage when students take their education to tertiary institutions that have a research mindset that is cultured and neatly structured like a doctoral higher education program.

\section{METHOD AND MATERIALS}

This study is a qualitative design that reviewed essential factors in the RSD framework's usefulness, and it can recommend to academics in Indonesian society. Besides, we also ensure that research has proven that research skills are essential for students and for those who are researchers, instructors, and learning policymakers in Indonesian universities. Given the available evidence that this research framework has widely applied among academics at Australian and foreign universities, we would like to review and explain the usefulness of this RSD framework for the Indonesian academic community. Therefore the study of Kim et al., (2012) argues that the review study method is a suitable method for assessing benefits, and using research skills among universities is constructive.

To facilitate this study, we have reviewed several documents related to the concepts and aspects of this RSD, history, initiators, study studies, applications, evaluations, the relevance of rubrics as assessments, and their appropriateness in the application J. W. Willison (2012) also said that academics could integrate development. Research skills, in terms of innovation and development of higher education curricula. That is what convinced us to compile this review. Furthermore, we document it as an introduction to the research development framework, specifically studied the RSD framework among students, especially those who completed academic tasks involving research skills for publication purposes to assess scholarly communication.

\section{RESULTS AND DISCUSSION}

Here is the Research Skill Development framework formate written in an Australian and New Zealand standard. 


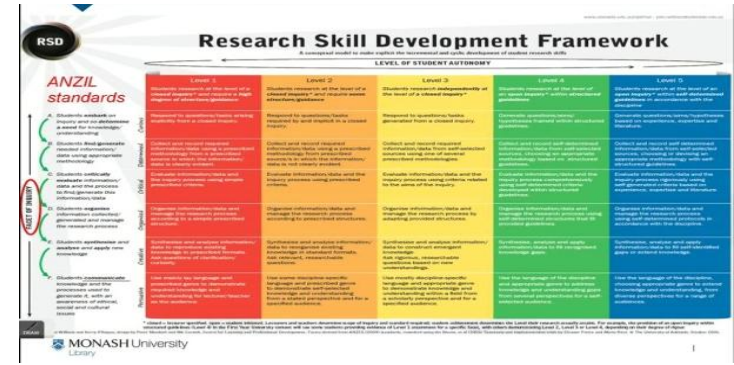

Sources: Monash University Library

This review describes the usefulness of the Research Skills Development Framework (RSD) for the higher education community in Indonesia. We report this finding review to developing the academic community in higher education study that is very applicable when learning involves research activities to guiding academics in developing student learning in higher outcomes. Furthermore, this review can also help facilitate distinctive learning in universities and other training institutions, to push learning attainment to the higher order-of-thinking skills expected by innovators and curriculum developers in Indonesia. Furthermore, this study framework is basically about conceptual research initiated by J. Willison \& O'Regan, (2007) of the University of Adelaide in 2007. The model of the RSD framework is easy to understand. Because in the concept, there are only six components of essential skills: the level of independence of students or researchers.
The following shows how a conceptual framework for developing research skills went to development to assist academics as students, teachers of university staff, and researchers.

If we look closely, all the RSD framework components are similar to Bloom's taxonomy concept. (Aslan \& Suhari, 2018; Ugur \& Koc, 2015), where the concept allows students' selfdevelopment to grow and develop level thinking towards a low-level theory of high-level or complex intelligence and in the application description of the mind. In this review, we want to explain that every student or researcher wants to learn something so that they can start from the perspective.

\section{To embark and inquiry} information- This initial step in which the researcher refers to an effort to set out to gain an understanding of what he wants to study. It means that the researcher must first understand the study question, its complexity and scope before the researcher or student finds out answers, and develop more specific questions in whatever field he is investigating. Thus, he will determine the need for data or information that can answer the problems of his study.

\section{To finding and generate} information This facet occupies the 
necessary second step when students undertake a particular study using an appropriate and appropriate methodology. This process is essential when students want to determine how to collect data or information for any study purposes in the research world. Because with the right methodology, students will be able to meet the elements desired by the audience or publication. So the effort to find this information will determine the validity and accuracy of the data that the researcher will use in the next stages.

\section{To critically evaluating the} information: This is a step that ranks in the RSD facet in the third step. This stage is carried out by a student or researcher to find data after the researcher considers it according to the problem formulation. This step has been done a lot as a condition in all research steps. This phase is vital because not all the data found cannot be used if they have not passed the evaluation stage regarding the data's relevance and accuracy. So students must have the skills to ensure that the data source is credible. Furthermore, efforts to evaluate information will encourage researchers to think logically and critically about the above elements, such as validity,authority, punctuality, or partial data.

\section{To organizing data and information}

After the above stages, now the researcher arrives to try to write down the data findings after the evaluation stage of the various study standard considerations that are required. The writing process must carry out by following the research questions with the language and writing system expected by either the organization or the purpose of the publication. Writing or organizing this Data can be in a qualitative or mixed form. All data, tables, and other graphs must be according to the reporting system of each discipline of knowledge and follow an appropriate reference system.

\section{To synthesizing and analyzing}

These skills are essential skills in conducting research where this skill tries to conclude all relevant data and information and answer study questions. This skill can build an in-depth understanding of inconsistencies in determining the choice of data from much evidence, and this skill can mark gaps in the research evidence so that all data presented meets the principles of validity and reliability.

\section{To communicating knowledge and}

\section{understanding}

This facet is the final step in researching the RSD framework domain. So communicating correct information based on the results after a series of phases 
in the previous steps. This last facet conveys the effectiveness of the researcher's findings in an acceptable communication approach in a particular area of expertise, through the ability and capability of researchers to interpret the data of their work. The skill of communicating information in research is carried out to facilitate scientific communication in the world of knowledge and help audiences understand the construction of communication in the world of knowledge and expertise.

This review study aimed to understand the principles of using the RSD conceptual framework for later developing study skills in Indonesian academies. The results of the review of research skills development have made many researchers, especially beginners such as students, to immediately engage in research activities after gaining an understanding of every aspect of the RSD framework that we have defined. These findings tell researchers and students how easy it will be for teachers to help students implement various learning methods and provide students with understanding not to see research efforts as complicated and challenging. (Abdurrahman et al., 2017). They added that the RSD framework has changed the international postgraduate students' thought and perception. These students also perceived this conceptual research framework a frightening lesson to deal. However, after being exposed several times, they finally enjoyed it and promised to use RSD in teaching and working. The findings of this review of the RSD framework are in line with the study results by J. Willison \& Buisman-Pijlman, (2016), which have integrated assessment rubrics as feedback in encouraging the development of research skills at the academic level in many research activities in postgraduate programs. Finally, these findings are significant to straighten perceptions in carrying out academic tasks that involve any research efforts.

Komarraju et al., (2010) examined the importance of the role of interaction between students and faculty in developing concepts of academic self-evaluation, motivation, and student achievement. So the results of this review on the use of RSD remind academics to increase the relevance of teaching objectives in Indonesian universities. Here, the rubric's role must play an interactive role, giving balanced feedback between those who assess and those who tobe assessed. Universities can better prepare students with research skills to efficiently complete college with rich research skills. It also makes it easier for alumni to plan for further studies at universities that have 
cultivated research skills and the demands of the world of work that involve these skills.

The findings of Pretorius et al., (2013) have also aligned constructively the framework for developing research skills with the use of theory to align the quality of graduates, academic experience, and assessment work at the undergraduate level. Likewise, RSD's findings have been shown to align teaching in tertiary institutions with research skills to strengthen academic identity. The findings from this review also inform that the RSD framework is not just a non-application concept. However, this research concept has contributed to developing new knowledge and expertise in each of these sciences. On the other hand, RSD is also a means to develop knowledge and facilitate research-based learning from an early age in schools. In other words, this RSD study has provided a new understanding of various concepts and made the university community aware that this can encourage the momentum of successful learning. With the findings of RSD, research-based studies will be an effort to improve research practices in independent learning that are practical towards academic productivity (Willison \& Buisman-Pijlman, 2016).
Lee and Sloan (2015) suggested that rubric can comprehensively evaluate instructional implementation in practical higher education learning. Here, it is evident that the rubric's implementation into teaching is no longer a foreign thing in technology and information education. In this case, our study's findings are one of the strengths and strengths of the RSD framework is the built-in rubric used to assess the academic work results of both students and lecturers. This rubric is prepared based on the criteria of the assessment elements or a measurable assessment model. This RSD requires the teacher to design a rubric by considering essential things so that the rubric design can connect and follow the learning outcomes of a semester. Thus, the use of rubrics in the RSD framework will explain the assessment criteria and help maintain consistency between the lesson content and the evaluated elements.

This RSD framework study results suggest that higher education teachers can develop a rubric based on the RSD framework, and the rubric follows the chosen reference principle. Furthermore, Jonsson, (2014) stated that an assessment tool is one way of evaluating education content transparently in universities. In other words, the rubric must be an instrument of assessment and evaluation in 
the higher education learning environment. In line with that, the RSD framework also suggests that the rubrics can be compiled collaboratively by involving course coordinators, course teams, teaching, learning specialists, and various scientific disciplines. To ensure the tool's composition is appropriate so that the assessment of learning outcomes in higher education becomes an example for other education levels in Indonesia according to the desired level of learning. In line with these findings, Stevens \& Levi, (2013) suggest that the use of terms rubrics is a tool in assessing the principle of saving time, constructive feedback, thereby encouraging student learning in tertiary institutions required to learn with the broadest autonomy. The RSD study findings and other frameworks have a strong association with broadened student autonomy and transparency. Finally, these findings imply the development of an RSD-style grading rubric for the assessment of specific subjects. Several stages and elements need to consider so that the rubric of innovation results makes it easier to assess students' work in tertiary institutions.

The findings from the discussion and interpretation of the review of the RSD framework and the discourse process of its application in Indonesia left many educational actors, deficient achieving students, and novice researchers because they mostly learn and work from a preknowledge base of various research and development-based learning methods in the field. These weaknesses and limitations will make it challenging to apply researchbased learning and evaluation of learning, such as the Australian national education leader's RSD framework, as one of Asia's leading educational and teaching innovations. For that, students and other components need to be proactive learners and researchers as long as they interact with all research-based learning models in each learning and working institution in Indonesia so that these difficulties and limitations can minimize as low as possible. Apart from research mindset culture, language limitation is another issue confronting Indonesian educators to collaborate in the international education research context. This what Sawir et al., (2012) ever wrote, the language difficulties experienced by most international educators and students joining international education communities such as learning in Australian based education spectrum is another issue to be this findings limitation. 


\section{CONCLUSION}

This review research aimed to reviewed the usefulness of the RSD framework, which has become the reference framework for researching the world of higher education in several developed countries. Adhering to the introduction, problem formulation, methods, results, discussion, and discussion of this review's course and flow, we can conclude some simple conclusions. This RSD framework has six research facets, forming a vertical developed at one of Australia's leading universities, namely the University of Adelaide. The framework of this RSD has a horizontal framework describing the level of students' ability to learn and work autonomously. This framework has five levels of student autonomy that are differentiated based on the degree of processing ability and the extent to which the resolution of answers integrates existing student and research understanding and produces new knowledge in RSD-owned rubrics with six research aspects five levels of autonomy. Students move as moving from a low level of independence requires lecturers' structure and guidance to a high autonomy level. Therefore, with research evidences from the findings of ten international papers reviewed, they can be a useful and help research framework that can be adopted to support Indonesian researchers and postgraduate students who work with academic works the require a rich research mindset and competencies.

\section{REFERENCES}

Abdurrahman, D., Willison, J., \& Sabir, F. (2017). International postgraduate students' perception of the research skill development framework. National Conference on Teachers' Professional Conference, 1(0), 77-81.

Aslan. (2018). Kajian Kurikulum Fiqih Pada Madrasah Aliyah Di Kabupaten Sambas Kalimantan Barat Pada Masyarakat Perbatasan. Madinah: Jurnal Studi Islam, 5(2), 115-124.

Aslan. (2019). Hidden Curriculum. Pena Indis.

Aslan, \& Suhari. (2018). Pembelajaran Sejarah Kebudayaan Islam. Razka Pustaka.

Aslan, \& Wahyudin. (2020). Kurikulum dalam Tantangan Perubahan. Bookies Indonesia.

Baker, V. L., \& Pifer, M. J. (2011). The role of relationships in the transition from doctoral student to independent scholar. Studies in Continuing Education, 33(1), 5-17.

Fortuin, K. P. J., \& Van Koppen, C. S. A. (2016). Teaching and learning reflexive skills in inter-and transdisciplinary research: A framework and its application in environmental science education. Environmental Education Research, 22(5), 697-716. 
Jonsson, A. (2014). Rubrics as a way of providing transparency in assessment. Assessment \& Evaluation in Higher Education, 39(7), 840-852.

Kim, S. H., Lee, J. L., \& Thomas, M. K. (2012). Between purpose and method: A review of educational research on 3D virtual worlds. Journal For Virtual Worlds Research, 5(1).

Komarraju, M., Musulkin, S., \& Bhattacharya, G. (2010). Role of student-faculty interactions in developing college students' academic self-concept, motivation, and achievement. Journal of College Student Development, 51(3), 332-342.

Laidlaw, A., Aiton, J., Struthers, J., \& Guild, S. (2012). Developing research skills in medical students:

AMEE Guide No. 69. Medical Teacher, 34(9), e754-771. https://doi.org/10.3109/0142159 X.2012.704438

Mataniari, R., Willison, J., Hasibun, M. E., Sulistiyo, U., \& Fatria, D. (2020). Portraying Students' Critical Thinking Skills through Research Skill Development (RSD) Framework: A Case of a Biology Course in an Indonesian University. Journal of Turkish Science Education, 17(2), 302-314.

Pretorius, L., Bailey, C., \& Miles, M. (2013). Constructive Alignment and the Research Skills Development Framework: Using Theory to Practically Align Graduate Attributes, Learning Experiences, and Assessment Tasks in Undergraduate Midwifery. International Journal of Teaching and
Learning in Higher Education, 25(3), 378-387.

Sawir, E., Marginson, S., Forbes-Mewett, H., Nyland, C., \& Ramia, G. (2012). International student security and English language proficiency. Journal of Studies in International Education, 16(5), 434454.

Stevens, D. D., \& Levi, A. J. (2013). Introduction to rubrics: $A n$ assessment tool to save grading time, convey effective feedback, and promote student learning. Stylus Publishing, LLC.

Torres, L., \& Jansen, S. (2016). Working from the Same Page: Collaboratively Developing Students' Research Skills Across the University. Council on Undergraduate Research Quarterly, $37(1)$.

Ugur, N. G., \& Koc, T. (2015). Time for digital detox: Misuse of mobile technology and phubbing. ProcediaSocial and Behavioral Sciences, 195, 1022-1031.

Wibawa, S. (2017). Tridharma Perguruan Tinggi (Pendidikan Dan Pengabdian Kepada Masyarakat). Disampaikan Dalam Rapat Perencanaan Pengawasan Proses Bisnis Perguruan Tinggi Negeri. Yogyakarta, 29, 01-15.

Willison, J., \& Buisman-Pijlman, F. (2016). PhD prepared: Research skill development across the undergraduate years. International Journal for Researcher Development.

Willison, J., \& O'Regan, K. (2007). Commonly known, commonly not known, totally unknown: A framework for students becoming researchers. Higher Education 
Nidhomul Haq, Vol 5 No 3. Tahun 2020

Research \& Development, 26(4), 393-

409.https://doi.org/10.1080/0729

4360701658609

Willison, J. W. (2012). When academics integrate research skill development in the curriculum.

Higher Education Research \& Development, 31(6), 905-919. 